() Кірєєва Д.О., Шевчук С.Г., 2021

doi: 10.37321/nefrology.2021.29-07

УдК: 616-378

\title{
НИКУЛА ТАРАС ДЕНИСОВИЧ - ШЛЯХИ ЖИТТЯ
}

\author{
КІРЄЄВА Д.О., ШЕВЧУК С.Г. \\ Національний медичний університет імені О. О. Богомольця \\ Київ, Україна
}

Резюме

Ключові слова: Тарас Денисович Никула, нефрологія, університет, вклад в науку, досягнення, історія. науковця, завідувача кафедри пропедевтики внутрішньої медицини №2, лікаря, видатного представника професорсько-викладацького склада Національного медичного університету імені О.О Богомольця, життєвий шлях якого висвітлений в цій роботі.

Мета роботи. Дослідження історичних даних про життя та наукові дослідження Никули Тараса Денисовича, його внесок в медицину.

Матеріали та методи. Аналіз літератури та статей, що містять біографічні дані про Т.Д. Никулу, аналіз його наукових робіт.

Результати та їх обговорення. Тарас Денисович Никула - видатний український науковець, лікар, професор, завідувач кафедри пропедевтики внутрішньої медицини №2 з 1988 по 2014 роки, талановита людина, автор 933 наукових робіт, у тому числі 54 винаходів, 74 навчальних посібників, монографій, підручників. Він вніс свій вклад в розвиток вітчизняної та світової медицини, зокрема таких галузей як гастроентерологія, нефрологія, кардіологія, ревматологія. Він не тільки здобував нові наукові дані, але і поширював їх серед медичної спільноти, створив школу нефрологів, був головним редактором щорічника “Актуальні проблеми нефрології”.

Висновки. В українській медицині є науковці, якими ми можемо пишатися, Т.Д. Никула зробив величезний вклад в розвиток медичної науки та передав свій досвід наступним поколінням лікарів.

Вступ. Никула Тарас Денисович - видатний

Вступ. Никула Тарас Денисович - видатний український науковець, лікар, професор, завідувач кафедри пропедевтики внутрішньої медицини №2 з 1988 по 2014 роки, талановита людина, автор 933 наукових робіт, у тому числі 54 винаходів, 74 навчальних посібників, монографій, підручників.

Мета роботи. Привернути увагу спільноти до кращих представників медичної науки України. Дослідження історичних даних про життя та наукові досягнення Никули Тараса Денисовича, його внесок в українську та світову медицину.

Матеріали та методи. Огляд сучасних джерел, що містять біографічні дані про Т.Д. Никулу, аналіз наукових робіт та узагальнення даних літератури.

Результати та їх обговорення. Тарас Денисович народився у селі Банилів (Чернівецька область) в сім'ї хліборобів 5 січня 1936 року [2]. Вже з дитинства в нього проявилися тяга та здатність до навчання, він вільно володів двома мовами, цікавився літературою, відмінно навчався в школі. Доля майбутнього лікаря була складною: Дру-

га Світова Війна, окупація рідних земель, голод, тяжкий стан здоров'я родичів, ув'язнення батька в румунській та радянських тюрмах [5]. Можливо, таке складне дитинство і виховало стальну силу характера, а проблеми зі здоров'ям рідних спрямували його освоїти найблагороднішу професію лікаря, і він продовжив своє навчання на лікувальному факультеті Чернівецького державного медичного інститута.

Никула Т. Д. мав успіхи в навчанні, 1960-го року закінчив інститут з відзнакою[2]. Талановитий студент звернув на себе увагу, йому було запропоновано місце в аспірантурі. Але молодий лікар відмовився від пропозиції та пішов працювати у лікарню у свій рідний район, набувати лікарський досвід, й одночасно викладав терапію у медичному училищі. У лікарні він обіймав посади завідувача терапевтичного відділення та головного лікаря [5].

За 5 років важкої роботи в лікарні Никула Тарас Денисович заробив достатньо досвіду та вирішив продовжити навчання, пов“язавши своє життя з Національним медичним університетом імені О. О. Богомольця[2]. 
Тарас Денисович вступив до клінічної ординатури, і в подальшому в аспірантуру на кафедру терапії стоматологічного факультета, де навчався у самого професора Анатолія Петровича Пелещука. Окрім Т. Д. Никули, у Пелещука навчалися ще Л.А. Пиріг (який в подальшому очолив lHститут нефрології), професори А.С. Свінціцький, П.М. Боднар, А.Д. Тодоренко та інші [10]. Саме на цій кафедрі було створено відділ терапевтичної нефрології.

За словами Никули Тараса Денисовича, даний етап був найвагомішим у його становленні як лікаря і науковця, бо саме у цей період він навчався у найдосвідченіших професорів, та визначився зі своїми науковими інтересами: нефрологія, кардіологія, гастроентерологія, ревматологія [4].

У 60-х роках, коли Тарас Денисович ще тільки починав свою кар“єру лікаря, нефрологія в Україні була розвинута слабко. Вона зародилася як наука ще у 20-х роках, але лише через 40 років було засновано відділ терапевтичної нефрології[8], який очолив Анатолій Петрович Пелещук, - 3 цього етапу розпочався стрімкий розвиток нефрології в Україні. А. П. Пелещук не тільки передав свій досвід та знання учням, але вони разом продовжували досліджувати патогенез, лікування та профілактику хвороб нирок [10].

Завдяки працьовитості, спраги до знань, закоханості в медицину, Никула Тарас Денисович пройшов важкий шлях від ординатора до поважного професора. У 1969 році захистив кандидатську дисертацію на тему «Вільні амінокислоти сироватки крові та сечі при дифузних захворюваннях нирок». У 1984 році захистив докторську дисертацію «Клінічна оцінка та лікування порушень амінокислотного обміну при нирковій недостатності», а через 4 роки очолив кафедру пропедевтики внутрішньої медицини № 2, якою керував 26 років [2].

Т.Д. Никула працював над вивченням гломерулонефриту та хронічної ниркової недостатності, разом з професором А. П. Пелещуком вони впровадили такі методи лікування як гемодіаліз, перитонеальний діаліз, трансплантація нирки, лікування кортикостероїдами; удосконалювали і старі методи лікування за допомогою сечогінних та гормональних засобів. Була розроблена спеціальна програмна дієтотерапія для хворих на хронічну хворобу нирок, покращена діагностика хвороб нирок за допомогою доступних на той час інструментів та інноваційних методів. Таким чином, були не тільки розроблені нові методи лікування та діагностики, вивчені ланки патогенезу, але вони були засновані на кращих традиціях Київської терапевтичної школи, закладених В. П. Образцовим, М. Д. Стражеско, Т. Г. Яновським, з дотриманням принципу «ближче до хворого» [10].
Здобувши величезний досвід у нефрології, Никула Тарас Денисович продовжив справу свого вчителя та заснував власну школу терапевтів, нефрологів[2]. Студенти Т.Д. Никули визначають, що його лекції та навчальні матеріали завжди визначалися чіткістю, послідовністю, актуальною інформацією, а професор підтримував студентів, які зацікавлені в науці. Він надихав студентів та молодих лікарів, був для них наставником та мудрою людиною, яка завжди дасть пораду.

Учні Т.Д. Никули стали спеціалістами в своїй галузі, причому не тільки в Україні, але і в США, Канаді, Німеччині та інших країнах. Серед його послідовників $€ 4$ доктори, 21 кандидат медичних наук, 8 магістрів медицини, деякі викладають на кафедрі пропедевтики внутрішньої медицини №2[7]: д.м.н. Палієнко Ігор Анатолійович, який зокрема досліджував фітотерапію в нефрології; д.м.н. Трунова Світлана Василівна (зараз доцент кафедри внутрішньої медицини №4), яка досліджувала остеохондроз, вісцеропатії, артеріальну гіпертензію, рефлексотерапію; кандидат медичних наук Манжалій Еліна Георгіївна почала виконувати докторську наукову роботу під керівництвом Т.Д. Никули і успішно захистила вже з новим науковим керівником, теж його ученицею, професором Мойсеєнко В.О., яка $є$ професором тієї ж кафедри.

Тарас Денисович надихнув і своїх дітей стати лікарями: старший син, Борис Тарасович, став лікарем-урологом, а донька, Олена Тарасівна, лікарем-генетиком, кандидатом медичних наук [6].

Іншим шляхом поділитися знаннями та досвідом, став щорічний науковий збірник «Актуальні проблеми нефрологіі», заснований Т.Д.Никулою, де він був головним редактором. На теперішній час його справу продовжує професор В. О. Мойсеєнко. У щорічнику публікують новини у сфері нефрології, довідки з історії медицини, статті про методи лікування та патогенез хвороб нирок. У відділі гастроентерології журналу «Лікарська справа. Врачебное дело» Т.Д. Никула був науковим редактором [6].

Наукові роботи Т. Д. Никули були присвячені дослідженню порушень обміну сечової кислоти, залежності тяжкості депресії у пацієнтів з печінковою енцефалопатією від рівня цитокінів [11]; вивчав артеріальну гіпертензію та її зв'язок з подагрою [16]; вплив цукрового діабету на нирки та участь нирок в метаболізмі глюкози [17], кардіоренальний синдром; фітотерапію, ї̈ ефективність при лікуванні хвороб нирок.

Тарас Денисович Никула вважав, що одним з його досягнень було удосконалення дієти для пацієнтів з нирковою недостатністю, хронічним нефритом, гломерулонефритом [9]. Він запропонував варіанти малобілкових дієт №7А та 7Б, що мають такі переваги: включають білки з високою 
біологічною цінністю, достатньо гістидину, мінералів і вітамінів, але забезпечують позитивний азотистий баланс, збалансованість амінокислотного складу як при кожному, так і добовому прийманні їжі, що є принциповим (Никула Т.Д., Тодоренко А.Д., 2007)[15]. Були не тільки визначені норми кількості білка в раціоні та вивчені біохімічні аспекти даного питання, але і розроблені рекомендації щодо меню таких хворих. Т.Д. Никула адаптував ці норми під українські страви, щоб дієтотерапія була не тільки корисною, але і смачною, звичною для хворого.

Він обгрунтував патогенез хронічної ниркової недостатності і на цій основі опрацював її оригінальну класифікацію, алгоритм діагностики (Т.Д. Никула, 2003), переваги якого полягають в використанні в певній послідовності загальноприйнятих клініко-лабораторних методів діагностики.

Разом з В.О. Мойсеєнко Тарас Денисович Никула вивчав вплив радіаційного випромінювання на організм людини. Зокрема, було досліджено вплив катастрофи на Чорнобильській AEC на здоров'я ліквідаторів та інших жертв трагедії. Були описані радіаційні ураження нирок, променевий нефрит, особливості променевого ураження шлунку та стравоходу. За це Т. Д. Никула був нагороджений міжнародною медаллю імені Марії Кюрі[12].

Для здобуття нових знань та для поширення традицій Київської терапевтичної школи, Т. Д. Никула брав участь в міжнародних конференціях та конгресах, був не менше ніж в 30 країнах. Він очолював Центр міжнародних клінічних досліджень, призначався консультативним редактором Американського біографічного інституту в США, заступником генерального директора Міжнародного біографічного центру в Кембриджі. За свою діяльність за кордоном був нагороджений преміями: "Leaders for new century" (Інститут "Who is who", США), "Excellentia", meдаль "2000 famous people in XX century", "2000 famous intellectuals in XXI century" та "2000 famous scientists in XXI century" (Міжнародний біографічний центр в Кембриджі, 2000 та 2002), "Man of the year" $(2003,2010)$, "International scientist of the year" $(2003,2004)$ [6].

В Україні за свої заслуги був удостоєний Державної премії України в галузі науки і техніки за розробки в діагностиці, лікуванні та профілактики хвороб нирок; має звання «Заслужений діяч науки і техніки України» (2003) [1], орден «За заслуги» III ступеня, нагороду Ярослава Мудрого, відзнаку «Гордість медицини України», медаль «За успіхи в науково-педагогічній діяльності», медаль імені Стражеска, медаль імені Платона [6].

Але найкраща нагорода для будь-якого науковця - це повага колег, студентів, земляків, родини. Співвітчизники шанують Тараса Денисовича, розповідь про нього присутня в книгах «Буковина. Імена славних сучасників», «Серцем 3
Буковиною» [5]. Незважаючи на те, що переважну частину життя Т. Д. Никула жив у Києві, він не забував про рідну Буковину та започаткував там відкриття бальнеологічного курорту.

Про винятковий патріотизм Тараса Денисовича свідчить і його любов до рідної мови. Він сприяв тому, щоб навчання в університеті проводилося українською мовою, видавав медичні тлумачні словники, що містили медичну термінологію українською, російською, англійською та латинською мовами[13].

Тарас Денисович був не тільки видатним лікарем, але і талановитою людиною $з$ широким колом інтересів: захоплювався класичною та сучасною літературою, українською поезією, грав у шахи, співав, мандрував світом. Про свій багатий життєвий досвід писав в мемуарах: «Родом із Буковини», «Життя і медицина» [13].

Висновки. Никула Тарас Денисович був не тільки успішним науковцем, професором, досвідченим лікарем, але і людиною, яку поважали оточуючі. Для студентів він був та залишається надалі прикладом для натхнення.

За свої 83 роки життя Тарас Денисович вніс величезний вклад в розвиток медицини в Україні та за кордоном. Він не тільки здобував нові знання, але і поширював їх: був автором навчальної літератури, редактором медичних видань, одним

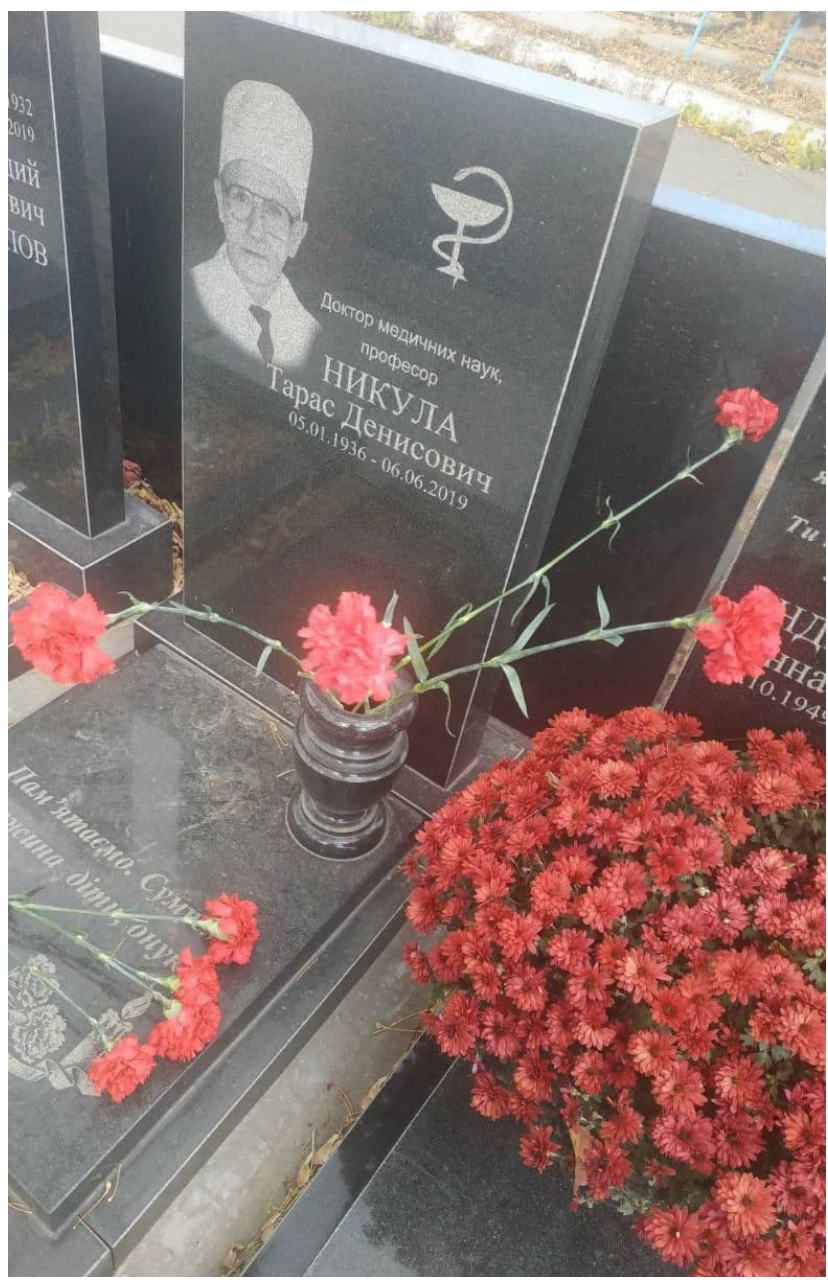


із засновників школи нефрологів, зробив внесок в розвиток кафедри пропедевтики внутрішньої медицини №2 Національного медичного університету імені О. О. Богомольця.

\section{ЛITЕРАТУРА}

1. Указ Президента України Про присудження Державних премій України в галузі науки і техніки 2009 року від 30.11.2009 https:// zakon.rada.gov.ua/laws/show/979/2009\#Text

2. Випускників твоїх славетні імена/ Т.М. Бойчук, В.Ф. Мислицький, В.Т. Бачинський, B.В. Білоокий, О.І. Іващук, О.Ф. Кулик, С.С. Ткачук, М.Д. Лютик // Видавництво Чернівці: »Місто». - 2014. - с. 240. http:// vipusknik.bsmu.edu.ua/pisch/nikula-tarasdenisovich

3. Пам'ять: академік Никула Тарас Денисович. Український медичний ліцей Національного медичного університета ім. О.О. Богомольця uml.ua/news/pam-iat-akademik-nykula-tarasdenysovych/

4. Тарас Никула: “Наступним етапом розвитку нефрології має стати прийняття консенсусу”. Медична газета “Здоров'я України” №62 січень 2003. https://health-ua.com/article/ 19335-taras-nikula-laquonastupnim-etapomrozvitku-nefrolog-ma-stati-prijnyattya-k

5. Ботушанський В.M. Чернівецький національний університет імені Юрія Федьковича. Імена славних сучасників. Київ, 2005. С. 1435, 92-104i https://bukportret.info/vizhnitskiyrayon/baniliv/vidatni-osobistosti-baniliv/

6. Тарас Денисович Никула (до 75-річчя від дня народження). Науковий вісник Національного медичного університета імені О.О. Богомольця №1(32). Київ, 2011. - С. 230-231

7. Історія кафедри пропедевтики внутрішньої медицини №2. Доступно на: http://nmuofficial. com/zagalni-vidomosti/kafedri/departmentpropaedeutics-internal-medicine-2/istoriyakafedry/

8. Історія Інституту нефрології НАМН України. Доступно на: http://inephrology.kiev. ua/?page_id=1637

9. Никула Т.Д., Мойсеєнко В.О., Наумова О.О. Українські малобілкові страви та амінокислоти / кетокислоти в лікуванні хронічної хвороби нирок.Актуальні проблеми нефрології: Збірник наукових праць (Вип. 19) / За ред. Никули Т.Д./ МОЗУ, НМУ. - Київ: Задруга, 2013. - C. 7-21. https://apn.co.ua/19/nykula. pdf

10. Свінціцький А.С., Дземан М.І. Сторінки життя та діяльності Анатолія Петровича
Пелещука. Журнал “Внутренняя медицина" 4(10) 2008 http://www.mif-ua.com/archive/ article/5648

11. Манжалій Е.Г., Вірченко О.В., Никула Т.Д., Бондур В.В., Мойсеєнко В.О., Кондаурова А.Ю. Залежність тяжкості депресії у пацієнтів з печінковою енцефалопатією від рівня цитокінів. Лікарська справа. - 2016. - N 5-6 (1139). - C. 56-65. https://www.researchgate. net/publication/319392451_E_G_Manzalij_O_V_ Vircenko_T_D_Nikula_V_V_Bondur_V_O_ Mojseenko_A_U_KondaurovaZaleznist_ tazkosti_depresii_u_pacientiv_z_pecinkovou_ encefalopatieu_vid_rivna_citokiniv_Likarska_ sprava_-_2016_-_N_5-6_1139_

12. Никула Т.Д. До річниці чорнобильської катастрофи: медаль імені Марії Кюрі за здобутки в галузі радіаційної медицини. Медичні кадри. - 2017. - №7-8. - С. 3. https://www. researchgate.net/publication/316940384_ TDNikulaDo_ricnici_cornobilskoi_ka-tastrofi_ medal_imeni_Marii_Kuri_za_zdobutki_v_ galuzi_radi-acijnoi_mediciniMedicni_ kadri-_2017-_No7-8-_S_3

13. Тарас Денисович Никула. До 85-ї рідниці. Національна наукова медична бібліотека України. https://library.gov.ua/tarasdenysovych-nykula-do-85-yi-richnytsi/

14. НикулаТ.Д., СиняченкоО.В., СемидоцькаЖ.Д. Пропедевтична нефрологія. - Київ. «Задруга», 2003. - 148 c. https://www.researchgate.net/ publication/259622921_Nikula_TD_Sinacenko_ OV_Semidocka_ZD_Propedevticna_nefrologia Za_red_TD_Nikuli-_Kiiv_Zadruga_2003_-_148_s

15. Никула Т.Д., Тодоренко А.Д. Харчування людей (раціональне і дієтичне) - Київ, «Задруга», 2007. - 216c. https://www. researchgate.net/publication/273455645_ TD_Nikula_ADTodorenkoHarcuvanna_ludej_ racionalne_i_dieticne_Kiiv_Zadruga_2007_220_s

16. Синиця Юлія Павлівна, Кондратюк Віталій Євгенович, Никула Тарас Денисович, Тарасенко Оксана Михайлівна. Спосіб лікування хворих на подагру чоловіків у поєднанні 3 артеріальною гіпертензією. Патент України на корисну модель № UA 118006 U (2017.01) A61K 36/00 C07D 311/30 (2006.01) A61P 3/00 A61K 125/00 (2006.01) U MПK A61K 38/56 (2006.01) A61P 9/12 (2006.01) https://www.researchgate.net/ publication/319881042_Sinica_Ulia_Pavlivna_ Kondratuk_Vitalij_Evgenovic_Nikula_Taras_ Denisovic_Tarasenko_Oksana_Mihajlivna_ Sposib_likuvanna_hvorih_na_podagru_ colovikiv_u_poednanni_z_arterialnou_ gipertenzieuPatent_Ukraini_na 


\section{PEЗЮME}

\author{
НИКУЛА ТАРАС ДЕНИСОВИЧ - ПУТИ ЖИЗНИ \\ Киреева Д.А, Шевчук С.Г. \\ Национальный медицинский университет \\ имени А.А. Богомольца \\ Киев, Украина
}

Введение. 5 января 2021 года исполнилось 85 лет со дня рождения Никулы Т.Д., учёного, заведующего кафедры пропедевтики внутренней медицины №2, врача, выдающегося представителя профессорскопреподавательского состава Национального медицинского университета имени А.А. Богомольца, жизненный путь которого освящен в этой работе.

Цель. Исследование исторических данных про жизнь и научные достижения Никулы Тараса Денисовича, его вклад в медицину.

Материалы и методы. Анализ литературы и статей, которые содержат биографические данные про Т.Д. Никулу, анализ его научных работ.

Результаты и их обсуждение. Тарас Денисович Никула - выдающийся украинский учёный, врач, профессор, заведующий кафедры пропедевтики внутренней медицины №2 с 1988 по 2014 год, талантливый человек, автор 933 научных работ, в том числе 54 изобретений, 74 учебных пособий, монографий, учебников. Он внёс свой вклад в развитие отечественной и мировой медицины, в частности таких отраслей как гастроэнтерология, нефрология, кардиология, ревматология. Он не только приобретал новые научные данные, но и распространял их среди медицинского сообщества, создал школу нефрологов, был главным редактором ежегодника "Актуальные проблемы нефрологии".

Выводы. В украинской медицине есть учёные, которыми мы можем гордиться. Т.Д. Никула сделал огромный вклад в развитие медицинской науки и передал свой опыт следующим поколениям врачей.

Ключевые слова: Тарас Денисович Никула, нефрология, университет, вклад в науку, история.

\section{SUMMARY}

\section{THE LIFE PATH OF TARAS DENYSOVICH NYKULA}

Kirieieva D.O., Shevchuk S. H.

Bogomolets National Medical University Kyiv, Ukraine

Introduction. On the 5th of January, 2021, it would have been the 85th birthday of Taras Denysovych Nykula. Nykula was a scientist, the head of Propaedeutics Internal Medicine Department No. 2, a doctor, and an honored professorial and teaching staff representative at the Bohomolets National Medical University. This paper investigates Nykula's life path.

Goal. The research explores the life history data of Taras Denysovych Nykula, his achievements in the field of science, and his contribution to medicine.

Materials and methods. This paper analyses Nykula's science publications and the literature and articles, which contain his biographical data.

Results and discussion. Taras Denysovych Nykula is an honored scientist of Ukraine, doctor, and professor. During 1988-2014 he was the head of Propaedeutics Internal Medicine Department No. 2. Nykula is a talented person who published 933 science papers and 74 study aids as well as monographs, and textbooks. In addition to that, he made a contribution of 54 inventions. He contributed to the development of medicine in Ukraine and all around the world, which includes such medical fields as gastroenterology, nephrology, cardiology, and rheumatology. He did not only obtain new scientific data, but he also made it spread among the medical community. He created the school of nephrologists and was the editorin-chief of the Actual Problems of Nephrology yearbook.

Conclusions. There are scientists in the medicine of Ukraine to be proud of. Nykula made a large contribution to the development of medical sciences and shared his experience with new generations of doctors.

Key words: Taras Denysovych Nykula, nephrology, university, contribution to science, history.

\section{АВТОРСЬКА ДОВІДКА}

\section{Кірєєва Дар‘я Олексіївна \\ Національний медичний університет імені О.О. Богомольця \\ Студентка III курсу медичного факультету №1 \\ +380669989458 \\ dariakir47@gmail.com}

\section{Шевчук Світлана Григорівна}

Національний медичний університет імені О.О. Богомольця

Доцент кафедри пропедевтики

внутрішньої медицини №2

+380953151664

sveta.shevchuk@ukr.net

\author{
Киреева Дарья Алексеевна \\ Национальный медицинский \\ университет имени А. А. Богомольца \\ Студентка III курса медицинского \\ факультета №1 \\ +38066 9989458 \\ dariakir47@gmail.com
}

\section{Шевчук Светлана Григорьевна}

Национальный медицинский университет имени А.А. Богомольца Доцент кафедры пропедевтики внутренней медицины №2 +380953151664 sveta.shevchuk@ukr.net

\section{Kirieieva Daria}

Bogomolets National Medical University Third-year student at the Medical Faculty No. 1. +38066 9989458 dariakir47@gmail.com

\section{Shevchuk Svitlana}

Bogomolets National Medical University Associate Professor at Propaedeutics Internal Medicine Department No. 2. +380953151664

sveta.shevchuk@ukr.net 